\title{
Does Protein Kinase C Play a Pivotal Role in the Mechanisms of Ischemic Preconditioning?
}

\author{
Ben C.G. Gho, Yvonne E.G. \\ Eskildsen-Helmond*, Sandra de Zeeuw, \\ Jos M.J. Lamers*, Pieter D. Verdouw \\ Experimental Cardiology. Thoraxcenter and *Department of \\ Biochemistry (Cardiovascular Research Institute COEUR), Erasmus \\ University Rotterdam, Rotterdam, The Netherlands
}

Summary. This communication reviews the evidence for the pivotal role of protein kinase $\mathrm{C}$ in ischemic myocardial preconditioning. It is believed that several intracellular signalling pathways via receptor-coupled phospholipase $C$ and its "cross-talk" with phospholipase D converge to activation of protein kinase $\mathrm{C}$ isotypes which is followed by phosphorylation of until now (a number of) unknown target proteins which produce the protective state of ischemic preconditioning.

After briefly introducing the general biochemical properties of protein kinase $C$, its isotypes and the limitations of the methodology used to investigate the role of protein kinase $C$, studies are discussed in which pharmacological inhibition and activation and (immunore)activity and/or isotypes measurements of protein kinase $C$ isotypes were applied to assess the role of activation of protein kinase $\mathrm{C}$ in ischemic myocardial preconditioning.

It is concluded that definitive proof for the involvement of protein kinase $\mathrm{C}$ in preconditioning requires future studies which must focus on the isotype(s) of protein kinase $\mathrm{C}$ that are activated, the duration of action, cellular translocation sites and the identity and stability (of covalently bound phosphate) of phosphorylated substrate proteins.

Cardiovasc Drugs Ther 1996:10:775-786

Key Words. myocardial ischemia; infarct size; myocardial protection; ischemic preconditioning; protein kinase $C$; phospholipase C; phospholipase D

Ischemic preconditioning is not an organ specific phenomenon, as it does not only occur in the heart $[1,2]$, but also in kidney [3], liver [4] and skeletal muscle [5], while the brain is protected against the consequence of a new ischemic event at 24 hours after the preconditioning stimulus is applied [6]. Furthermore, brief ischemia in organs other than the heart may also limit irreversible damage produced by a subsequent coronary artery occlusion. Thus, in rats a 15-minute occlusion of the mesenteric artery with 10 minutes of reperfusion prior to a 60-minute coronary artery occlusion limited myocardial infarct size by $40 \%$ [7]. Since ganglion blockade abolished myocardial protection by mesenteric artery occlusion-reperfusion but not by brief coronary artery occlusion-reperfusion, the mechanism of protection by brief ischemia-reperfusion in other organs appears to differ from that by brief myocardial ischemia-reperfusion [7].

Initially, ischemic preconditioning studies focussed on time characteristics and the search for extracellular endogenous and exogenous factors that either mimicked or inhibited the phenomenon. It proved that protection occurred during two distinct episodes: a classical preconditioning period (CPP) that lasted 2 to 3 hours after the preconditioning stimulus was applied $[1,2]$, and a second window of protection (SWOP) between 24 and 72 hours [8-10]. The mechanisms of protection for these two windows are most likely not the same. Rapidly produced endogenous factors may activate intracellular pathways during $C P P$, while the slower process of induction of heat-shock proteins may be involved during the SWOP. Initially, attention focussed on activation of adenosine $A_{1}$-receptors $[11,12]$ or $\mathrm{K}_{\mathrm{ATP}}^{+}$channel opening [13,14] as the mechanisms for protection during CPP. More recently activation of protein kinase $\mathrm{C}$ has received wide attention [15]. Prior to reviewing the role of protein kinase $\mathrm{C}$, we review the current state of knowledge of the molecular mechanism(s) of ischemic preconditioning. introduce the generally known biochemical properties of protein kinase $\mathrm{C}$ and discuss the limitations of the techniques used to investigate the potential role of protein kinase C. Finally, the evidence that activation of protein kinase $\mathrm{C}$ and the intracellular signalling pathways leading to its activation play a pivotal role in the mechanism of ischemic preconditioning is sum-

Address for correspondence: Pieter D. Verdouw, $\mathrm{PhD}$, Experimental Cardiology, Thoraxcenter, Erasmus University Rotterdam, P.O. Box 1738, 3000 DR Rotterdam, The Netherlands, E-mail: Verdouw@tch.fgg.eur.nl

Received 10 June 1996; receipt/review time 70 days; accepted 13 September 1996 
marized. However, not all studies support a role for protein kinase $\mathrm{C}$ in preconditioning and this issue remains therefore controversial at the present time.

Most studies on ischemic preconditioning used infarct size as endpoint, but other endpoints such as recovery of contractile function, and protection against reperfusion-induced ventricular arrhythmias have also been used. Because these other endpoints require different experimental conditions (i.e. shorter duration of the sustained occlusions) we have limited ourselves to studies which used infarct size as endpoint. For this same reason we have excluded studies on ischemic preconditioning in other organs.

\section{Current State of Knowledge of the Molecular Mechanism(s) of Ischemic Preconditioning}

Activation of receptors by exogenously administered stimuli such as adenosine [11,12], bradykinin [16,17], noradrenaline $[18,19]$, acetylcholine $[20,21]$, endothelin-1 [22] or opiates [23] mimic myocardial protection by ischemic preconditioning. Intracellular signalling by these stimuli, via GTP-binding-protein-linked receptors and phospholipase $\mathrm{C}$ and possibly phospholipase D (see later) $[24,25]$, leads to activation of one or more isotypes of the protein kinase $\mathrm{C}$ family which then phosphorylate putative target proteins $[15,26]$. Possible target proteins are those that regulate opening of $\mathrm{K}_{\mathrm{ATP}}^{+}$channels $[13,14,27]$, activate ecto-5'nucleotidase [28] (during CPP) or modulate transcriptional regulation of the expression of heat shock proteins [29,30] (during SWOP). For instance, $\mathrm{K}_{\mathrm{ATP}}^{+}$ channels are opened when an ischemic preconditioning stimulus is applied, while blockade of $\mathrm{K}_{\mathrm{ATP}}^{+}$channels prevents ischemic preconditioning [13,14]. It is likely that modulation of $\mathrm{K}_{\mathrm{ATP}}^{+}$channels in the mitochondria, sarcoplasmic reticulum or the nucleus are involved in the mechanism of protection as blockade of the action potential shortening by dofetilide does not abolish protection by ischemic preconditioning [31]. Since protein kinase $\mathrm{C}$ can be activated via various receptors linked to phospholipase C- and possibly phospholipase Dmediated signalling pathways, these receptors may act synergistically [15]. Opening of $K_{A T P}^{+}$channels by pharmacological substances lowers the threshold for ischemic preconditioning [32], which is consistent with the hypothesis that $\mathrm{K}_{\mathrm{ATP}}^{+}$channels are target proteins for protein kinase C. Kitakaze et al [28] reported that ischemic preconditioning increased ecto-5'-nucleotidase activity and that activation of protein kinase $\mathrm{C}$ increases ecto-5' ${ }^{\prime}$-nucleotidase activity in isolated rat cardiomyocytes, supporting the candidacy of ecto-5'nucleotidase as another target protein of protein kinase $\mathrm{C}$.

\section{General Biochemical Properties of Protein Kinase C}

In general, the conformation of protein kinases consists of two regions which are connected by a region functioning as a hinge. The protein substrate fits into the groove between the two regions and interacts with a catalytic domain and cofactors interacting with the regulatory domain [33]. The specificity of protein kinases such as cyclic AMP dependent protein kinase, $\mathrm{Ca}^{2+}$-calmodulin dependent protein kinase (CaM-PK) and protein kinase $\mathrm{C}$ for their substrate proteins is determined by both the primary sequence of these proteins around their phosphorylation site and the capacity of these sites to interact with the catalytic domain of the protein kinase. Generally, protein kinases are inactivated by the interaction between a pseudo substrate region in the protein kinase's primary sequence and the active site [33]. This restraint is removed during activation by changes in protein kinase conformation due to interaction of second messengers (e.g. cyclic AMP, 1,2-diacylglycerol (1,2-DAG) and $\mathrm{Ca}^{2+}$ ) with the protein kinase's regulatory sites and by competition between the protein substrates and the pseudo substrate site, all present at the $\mathrm{N}$ terminal region of the primary structure of the protein kinases (Fig. 1). Indeed, activation of most protein Serine/Threonine (Ser/Thr) kinases is preceded by receptor activation followed by synthesis or release of low-molecular-weight protein kinase effectors or second messengers.

Protein kinases can be divided in several types. Protein kinase A is a cyclic AMP dependent proteinSer/Thr kinase, while protein kinase $\mathrm{C}$ is a group of protein-Ser/Thr kinases which are phosphatidylserine (PtdSer-), 1,2-DAG- and/or $\mathrm{Ca}^{2+}$-dependent. Recently, protein kinase D was discovered in COS cells to be dependent on 1,2-DAG and phorbol esters, but information on this enzyme in myocardium is not yet available [35]. In myocardial cells protein kinase $\mathrm{C}$ regulates various processes, including myocardial contraction, ion transport, energy metabolism, gene expression and hypertrophic growth $[25,36,37]$. The role of protein kinase $\mathrm{C}$ in growth and proliferation has been implied by its identification as a high-affinity intracellular receptor for tumor-promoting phorbol esters which directly activate most protein kinase $\mathrm{C}$ isotypes in a relatively unspecific manner. Phosphorylation of target proteins by protein kinase $\mathrm{C}$ isotypes depends on their intracellular location at the time of action. This compartmentalization may be caused by the architecture and intracellular localization of anchor proteins e.g. the so-called receptors for activated $\mathrm{C} \mathrm{ki-}$ nase (RACK) [38,39]. Therefore, after protein kinase C is activated it translocates to other cellular compartments such as the sarcolemma where it exerts its principal action (Fig. 1). However, several other compartments such as mitochondria, myofibrils, sarcoplasmic 

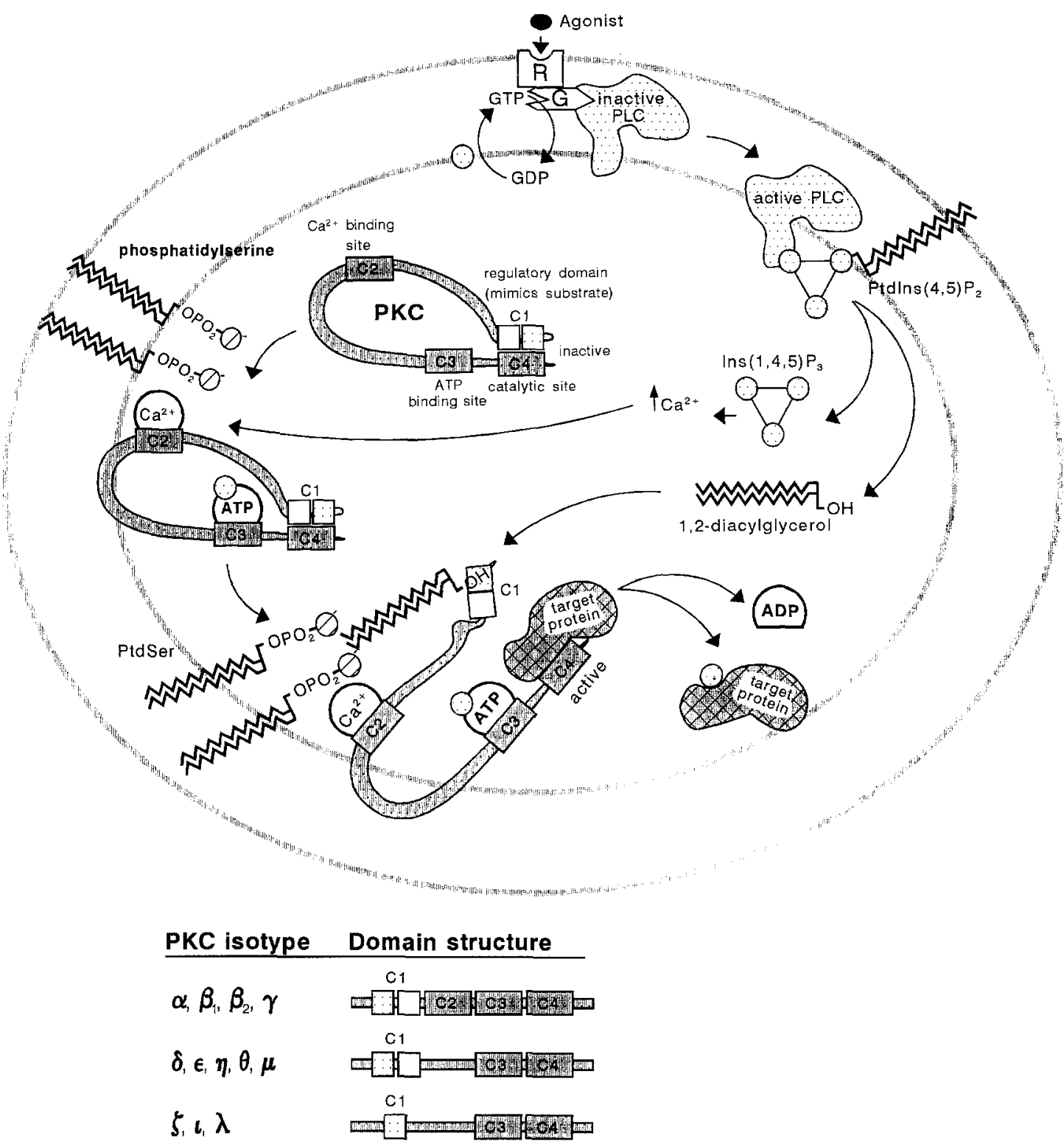

Fig. 1 Isotypes of protein kinase $C$, the functional domains in their primary structure, and receptor-coupled phospholipase $C$ mediated signal transduction leading to protein kinase $C$ activation. The various protein kinase $C$ isotypes share some sequence homology and have all a common ATP-binding site (C3) and catalytic site (C4). Only protein kinase $C-\alpha,-\beta_{1},-\beta_{2}$ and $-\gamma$ have $a \mathrm{Ca}^{2+}$ binding site (C2) and 1,2-diacylglycerol (1,2-DAG)-binding site (C1). In the inactivated state the isotypes of protein kinase $C$ are folded so that an endogenous "pseudo substrate" region on the $N$-terminal part of the protein occupies the catalytic site $(C$ terminal part). When agonists (see text) bind to their specific receptors linked to phospholipase $C$ in the cardiac sarcolemma, receptor activation is followed by phospholipase $C$ catalyzed hydrolysis of PtdIns $(4,5) P_{2}$ to form inositol-1,4,5-trisphosphate $\left(\right.$ Ins $\left.(1,4,5) P_{3}\right)$. Ins $(1,4,5) P_{3}$ releases $C a^{2+}$ from the Ins $(1,4,5) P_{3}$ receptor-sensitive $C a^{2+}$ storage sites in the cardiac sarcoplasmic reticulum. PtdIns $(4,5) P_{2}$ hydrolysis also forms 1,2-diacylglycerol $(1,2-D A G)$, which increases the affinity of some isotypes for Ca ${ }^{2+}$. When the intracellular free $\mathrm{Ca}^{2+}$ concentration increases, some isotypes become more tightly associated with membranes containing the negatively charged head groups of PtdSer, allowing 1,2-DAG to reach its binding site (C1) on the protein kinase C. The 1,2-DAG-protein kinase C complex approaches the membrane by placing the kinase in a pocket of negatively-charged head groups of PtdSer in which $\mathrm{Ca}^{2+}$ remains attracted. When this occurs, the conformation of protein kinase $C$ changes, exposing the unoccupied catalytic site, thereby allowing the kinase to phosphorylate cellular proteins. There is also evidence that specific binding proteins (e.g. MARCKS and RACK) determine the cellular translocation process of protein kinase C isotypes. The membrane-bound protein kinase $C-D A G-\left(\mathrm{Ca}^{2+}\right)$-membrane complex only slowly dissociates and this property is the basis for the commonly used "translocation assay" for assessment of PKC activation. Figure adapted from Zeisel et al [34], with permission of the FASEB Journal. 
reticulum and the perinuclear zone also possess specific receptor sites for protein kinase $\mathrm{C}$ isotypes [40].

\section{Protein Kinase C Isotypes}

The protein kinase $\mathrm{C}$ family can be divided into three distinct subfamilies on basis of their structure and catalytic and regulatory properties (Fig. 1). Classical protein kinase $\mathrm{C}$ isotypes (cPKC's) such as protein kinase $\mathrm{C}-\alpha,-\beta_{1},-\beta_{2}$ and $-\gamma$ are activated by $\mathrm{Ca}^{2+}$, PtdSer and 1,2-DAG or phorbol esters such as phorbol-12-myristate-13-acetate (PMA). Novel protein kinase C isotypes (nPKC's) such as protein kinase C- $\delta$, $-\epsilon,-\eta,-\theta$ and $-\mu$ are $\mathrm{Ca}^{2+}$ independent and only need PtdSer and 1,2-DAG (or PMA) to become activated. Atypical protein kinase $\mathrm{C}$ isotypes (aPKC's) are protein kinase $\mathrm{C}-\zeta,-\iota$ and $-\lambda$ which are also $\mathrm{Ca}^{2+}$ independent and only require PtdSer to become activated (Fig. 1). At present, the still growing number of isotypes can be discriminated by immunoblot or immunohistofluorescence analysis. Most investigators use histone III-S as substrate and $\gamma^{-32} \mathrm{P}$-labelled ATP as phosphate donor to measure protein kinase $\mathrm{C}$ activity, which reflects the activity of some of the isotypes present in the cellular fraction. Histone III-S is a poor substrate for some nPKC's ( $\delta, \epsilon$ and $\eta$ ) compared to the other isotypes $\left(\alpha, \beta_{1}, \beta_{2}, \gamma\right)$ [41]. Moreover, techniques such as hydroxylapatite high-pressure-liquidchromatography can be used to determine the activity of protein kinase $\mathrm{C}$ isotypes after separation [42]. Measurement of the mRNA concentration using specific cDNA probes on Northern blotting can also be used for the detection of protein kinase $\mathrm{C}$ isotypes [43], but mRNA levels offer only limited information because these do not always reflect the functional activities of the isotypes.

In a preliminary study it was found that $\alpha, \beta, \epsilon$ and $\zeta$ are the most prominent isotypes in the rat heart [44]. Similar observations have been made in cultured neonatal rat cardiomyocytes [45] and adult rat cardiomyocytes [46]. However, in a more recent study in adult rat ventricular myocytes, protein kinase $\mathrm{C}-\epsilon$ was abundantly present and protein kinase $\mathrm{C}-\alpha$ could not be detected $[47,48]$, while in another study protein kinase $\mathrm{C}-\alpha,-\delta,-\epsilon,-\eta,-\theta,-\zeta,-\lambda$ and $-\iota$ were detected in adult rat heart [49]. In the canine heart the presence of protein kinase $C-\alpha,-\beta_{1},-\beta_{2},-\gamma,-\delta,-\epsilon,-l,-\theta$ and $-\zeta$ has been described [50]. Thus, the species and the type of assays determine the pattern of protein kinase $\mathrm{C}$ isotypes. Furthermore, the affinity and the specificity of the antibodies used to detect the protein kinase $\mathrm{C}$ isotypes determine the abundancy of detection but not the absolute concentration of the isotype in vivo. In the pig, using rabbit polyclonal antibodies, we have demonstrated the presence of protein kinase $\mathrm{C}-\alpha$ and $-\epsilon$, while the isotypes $-\delta$ and $-\zeta$ were barely detectable. Other isotypes were not studied [51].
Myocardial homogenates do not only contain homogenized myocytes but also homogenized fibroblasts, smooth muscle cells and endothelial cells. Consequently, the protein kinase $\mathrm{C}$ isotypes of these cells in these homogenates are measured all together. So far, in only one study immunohistochemistry was used to detect the isotypes in situ [48]. In that study it was concluded that protein kinase $C-\delta$ is probably the most important isoform involved in preconditioning in the rat heart [48].

\section{Protein Kinase C in Coupling Phospholipase C- to Phospholipase D-activation}

Endogenous ligands such as adenosine $\mathrm{A}_{1^{-}}, \alpha_{1^{-}}$ adrenergic- and muscarinic agonists, bradykinin, angiotensin II, endothelin-1 or opiates stimulate, via the receptor-G-protein coupled to phospholipase $\mathrm{C}$, the intracellular signalling pathway $[25,48,52-56]$. Phospholipase $C$ catalyzes hydrolysis of phosphatidylinositol-4,5-biophosphate (Ptdlns $\left.(4,5) \mathrm{P}_{2}\right)$ which leads to formation of the second messengers inositol-1,4, 5-triophosphate $\left(\operatorname{Ins}(1,4,5) \mathrm{P}_{3}\right)$ and 1,2-DAG (Fig. 1) [25]. These messengers, directly or indirectly, activate $\mathrm{Ca}^{2+}$-independent and/or $\mathrm{Ca}^{2+}$-dependent protein kinase $\mathrm{C}$ isotypes and calmodulindependent protein kinase (CaM-PK). The activated protein kinase $\mathrm{C}$ isotypes and/or CaM-PK phosphorylate specific target proteins which may be responsible for CPP. Phospholipase D, another enzyme of which a stimulation leads to 1,2-DAG formation can be strongly stimulated by phorbol esters $[36,45,51,57,58]$. It uses phosphatidylcholine (PtdCho) as substrate and its activation leads initially to formation of phosphatidic acid (PtdOH) and choline [59]. $\mathrm{PtdOH}$ is rapidly hydrolysed to $1,2-\mathrm{DAG}$ and inorganic phosphate $\left(\mathrm{P}_{\mathrm{i}}\right)$ by PtdOH hydrolase. The 1,2DAG formed by phospholipase D potentially contributes to activation of protein kinase $\mathrm{C}$ isotypes [51]. Stimuli such as noradrenaline, angiotensin II and endothelin-1 stimulate both phospholipase $\mathrm{C}$ and phospholipase $\mathrm{D}[45,58,60]$. In fact, protein kinase $\mathrm{C}$ has been proposed to function as a switch which reduces the rate of $\operatorname{PtdIns}(4,5) \mathrm{P}_{2}$ hydrolysis catalyzed by phospholipase $\mathrm{C}$ and stimulates the rate of PtdCho hydrolysis catalyzed by phospholipase D $[57,58,59]$. Through this "cross talk" mechanism between phospholipase $\mathrm{C}$ and $\mathrm{D}$, the cardiomyocytes may be continuously supplied with 1,2-DAG after receptor stimulation, because the cellular concentration of PtdCho is about 100 times higher than that of $\operatorname{PtdIns}(4,5) \mathrm{P}_{2}$. The continuous production of 1,2-DAG could be of importance for maintenance of activation of the protein kinase $\mathrm{C}$ isotypes involved in ischemic preconditioning. 


\section{Evidence for a Role of Protein Kinase $C$ in Ischemic Preconditioning}

\section{Inhibition of protein kinase C (Table 1)}

Selective inhibition of protein kinase $\mathrm{C}$ activation by administration of inhibitors prior to or after applying the cardioprotective stimulus is one approach to investigate the role of protein kinase $\mathrm{C}$ in ischemic preconditioning. Depending on the inhibitor, protein kinase $\mathrm{C}$ function can be blocked at its catalytic or regulatory sites (Fig. 1). It is also possible to downregulate protein kinase $\mathrm{C}$ activity by prolonged (1-2 days) stimulation with phorbol ester [61]. This last approach has not been used in ischemic preconditioning, but is of interest in view of the development of tolerance to ischemic preconditioning when a very large number of brief occlusion-reperfusion sequences are applied [62].

The most prominent drugs used to inhibit protein kinase activation or translocation are staurosporine [17,48,52,63], 1-(5-isoquinolinesulfonyl)-2-methylpiperazine (H-7) [27,64], chelerythrine [53,65-67], calphostin-C [68], polymyxin B [17,52,55,56,64,66], bisindolylmaleimide $[28,69]$ and colchicine [63]. Staurosporine, $\mathrm{H}-7$, and polymyxin $\mathrm{B}$ are non-specific inhibitors of protein kinase $\mathrm{C}$ compared to cyclic AMP-dependent protein kinase, CaM-PK or protein-Tyr kinases [70]. All non-selective inhibitors act on the catalytic domain of protein kinase $\mathrm{C}$, which contains a high degree of sequence homology with other protein kinases. The more specific inhibitor calphostin-C [71] acts on the regulatory domain (Fig. 1). Chelerythrine, another specific inhibitor [67] interacts with the catalytic domain but also competes with the classically used protein substrates of protein kinase $\mathrm{C}$ [57]. Furthermore, polymyxin $B$ directly blocks $\mathrm{K}_{\mathrm{ATP}}^{+}$channels, one of the possible target proteins of protein kinase $\mathrm{C}$ and is therefore inappropriate to investigate the role of protein kinase $\mathrm{C}$ in ischemic preconditioning $[72,73]$. Moreover, it is unknown whether protein kinase C inhibitors are equipotent for all enzyme isotypes. It is quite feasible that the degree of inhibition depends on both the isotype [60,74-76] and species. Table 1 shows that polymyxin B [66], staurosporine [48] and chelerythrine [48] abolished the protective effect in isolated rat hearts and calphostin-C [68] and chelerythrine [53] in the in vivo rat model. Polymyxin B $[17,52,55,56]$ and staurosporine [17] abolished protection in in vitro and polymyxin B [52], staurosporine $[52,63]$, chelerythrine [67] and colchicine [63] in in vivo rabbit model. In dogs, the data are different as Przyklenk et al [64] observed that polymyxin B and H-7 did not abolish cardioprotection by ischemic preconditioning. In a preliminary study in pigs, staurosporine and bisindolylmaleimide limited infarct size [69]. These studies suggest a different role for protein kinase $\mathrm{C}$ in rats and rabbits than in dogs and pigs. The different results in rat, rabbit and pig could be related to species-dependent differences in myocardial expression, in the task performed and the site of translocation of the various isotypes [38,39,48,64,77]. Moreover, the various isozymes might be activated differently by $\mathrm{Ca}^{2+}, 1,2-\mathrm{DAG}$ and free fatty acids $[24,25,36,37]$.

Reviewing the studies using pharmacological blockade one is tempted to conclude that the protein kinase $\mathrm{C}$ family is involved in the mechanism of ischemic preconditioning in rat and rabbit. However, none of the studies investigated whether blockade of protein kinase $\mathrm{C}$ actually occurred in the in vivo model. In vitro assays of enzyme activity will not provide conclusive answers also because these have to be performed in subcellular fractions in the absence of the inhibitor due to the isolation procedure and in the presence of optimal amounts of 1,2-DAG and/or $\mathrm{Ca}^{2+}$. The ideal experimental design would be to study the enzyme activity in vivo by measuring phosphorylation degrees of one or more of the unknown specific target proteins.

\section{Activation of protein kinase C (Table 2)}

Activation of protein kinase $C$ by administration of phorbol esters, such as 12-0-tetradecanoyl phorbol13-acetate (TPA) and PMA [27,66] or 1,2-DAG analogues such as 1-stearoyl-2-arachidonoyl glycerol (SAG) [48], 1,2-dioctanoyl sn-glycerol (DOG) [65] and oleyl acetylglycerol (OAG) [64] prior to a sustained coronary artery occlusion has been a second approach to investigate the role of protein kinase $\mathrm{C}$ in ischemic preconditioning. The advantage of using phorbol esters over 1,2-DAG as activating substances is that they are not metabolized and produce prolonged protein kinase $\mathrm{C}$ activation. Protein kinase $\mathrm{C}$ translocation takes place after phorbol ester (or the 1,2-DAG analog) is bound to the enzyme's regulatory domain whereby it obtains not only an increased affinity for acidic membrane phospholipids (PtdSer) but also an increased activity (Fig. 1).

PMA and several 1,2-DAG analogs mimic preconditioning in the rat [53] and rabbit [52,63], but PMA failed to limit infarct size in pigs [69]. Przyklenk et al [64] measured protein kinase $\mathrm{C}$ translocation after administration of PMA in dogs. Although these studies lack information regarding activation (translocation) of the isotype(s) in relation to the protective effect, the results with activators suggest a role for protein kinase $\mathrm{C}$ in ischemic preconditioning in rat and rabbit. Furthermore, the route of administration and the dose used may be different for the large animal studies and the in vitro and in vivo studies of small animals. For instance, Vogt et al [69] used intramyocardial administration of PMA $(1 \mu \mathrm{M})$ to activate protein kinase $\mathrm{C}$ but failed to mimic the protective effect of ischemic preconditioning. However, the dose could have been too high because Cohen et al [78] found that $0.2 \mathrm{nM}$ PMA was protective, while $2 \mathrm{nM}$ PMA was damaging in the isolated rabbit heart. It is feasible 
Table 1. Protein kinase $C$ inhibitors and protection by ischemic preconditioning.

\begin{tabular}{|c|c|c|c|c|c|c|c|}
\hline Model & Species & $\begin{array}{l}\text { CP-Stimulus } \\
x(I+R)(\min )\end{array}$ & $\begin{array}{l}\text { Prolonged- } \\
\text { Ischemia } \\
\mathrm{I}(\mathrm{R})(\mathrm{min})\end{array}$ & Protein kinase $\mathrm{C}$ inhibitor & $\begin{array}{l}\text { Evaluation } \\
\text { (ISL/FR) }\end{array}$ & Result & Reference \\
\hline \multirow[t]{9}{*}{$\begin{array}{c}\text { Isolated } \\
\text { heart }\end{array}$} & \multirow[t]{2}{*}{ Rat } & $\begin{array}{l}3 x(5 I+5 R) \\
3 x(5 I+5 R)\end{array}$ & $\begin{array}{l}30 \mathrm{I}(120 \mathrm{R}) \\
30 \mathrm{I}(120 \mathrm{R})\end{array}$ & $\begin{array}{l}\text { Polymyxin B, before CP-stim } \\
\text { Chelerythrine, before CP-stim }\end{array}$ & $\begin{array}{l}\text { ISL } \\
\text { ISL }\end{array}$ & $\begin{array}{l}\text { Abolishes } \\
\text { Abolishes }\end{array}$ & [66] \\
\hline & & $\begin{array}{l}1 \times(2 \mathrm{I}+10 \mathrm{R}) \\
\text { Phenylephrine }+10 \mathrm{R} \\
1 \times(2 \mathrm{I}+10 \mathrm{R}) \\
\text { Phenylephrine }+10 \mathrm{R}\end{array}$ & $\begin{array}{l}20 \mathrm{I}(40 \mathrm{R}) \\
20 \mathrm{I}(40 \mathrm{R}) \\
20 \mathrm{I}(40 \mathrm{R}) \\
20 \mathrm{I}(40 \mathrm{R})\end{array}$ & $\begin{array}{l}\text { Staurosporine, before CP-stim } \\
\text { Staurosporine, before CP-stim } \\
\text { Chelerythrine, before CP-stim } \\
\text { Chelerythrine, before CP-stim }\end{array}$ & $\begin{array}{l}\text { FR } \\
\text { FR } \\
\text { FR } \\
\text { FR }\end{array}$ & $\begin{array}{l}\text { Abolishes } \\
\text { Abolishes } \\
\text { Abolishes } \\
\text { Abolishes }\end{array}$ & [48] \\
\hline & \multirow[t]{7}{*}{ Rabbit } & $1 x(5 I+10 R)$ & $30 \mathrm{I}(120 \mathrm{R})$ & $\begin{array}{l}\text { Staurosporine, before and after } \\
\text { CP-stim }\end{array}$ & ISL & $\begin{array}{l}\text { Failed to } \\
\text { abolish }\end{array}$ & \multirow[t]{4}{*}{ [17] } \\
\hline & & $1 \mathrm{x}(5 \mathrm{I}+10 \mathrm{R})$ & $30 \mathrm{I}(120 \mathrm{R})$ & Staurosporine, after CP-stim & ISL & Abolishes & \\
\hline & & Bradykinin & $30 \mathrm{I}(120 \mathrm{R})$ & Staurosporine, after CP-stim & ISL & Abolishes & \\
\hline & & Bradykinin & $30 \mathrm{I}(120 \mathrm{R})$ & $\begin{array}{l}\text { Polymyxin } \mathrm{B}, 50 \mathrm{~min} \text { starting } 5 \\
\text { min before CP-stim }\end{array}$ & ISL & Abolishes & \\
\hline & & $1 \times(5 I+10 R)$ & $30 \mathrm{I}(180 \mathrm{R})$ & $\begin{array}{l}\text { Polymyxin B, } 5 \text { min after } \\
\text { CP-stim }\end{array}$ & ISL & Abolishes & {$[52]$} \\
\hline & & Phenylephrine & $30 \mathrm{I}(120 \mathrm{R})$ & $\begin{array}{l}\text { Polymyxin B, before and after } \\
\text { CP-stim }\end{array}$ & ISL & Abolishes & {$[55]$} \\
\hline & & Angiotensin II & $30 \mathrm{I}(120 \mathrm{R})$ & $\begin{array}{l}\text { Polymyxin } \mathrm{B}, 50 \mathrm{~min} \text { starting } 5 \\
\text { min before CP-stim }\end{array}$ & ISL & Abolishes & {$[56]$} \\
\hline \multirow[t]{16}{*}{ In Vivo } & \multirow[t]{2}{*}{ Rat } & $1 x(5 I+10 R)$ & $45 \mathrm{I}(150 \mathrm{R})$ & Cheleythrine, after CP-stim & ISL & Abolishes & {$[53]$} \\
\hline & & $3 \times(3 I+5 R)$ & $90 \mathrm{I}(240 \mathrm{R})$ & $\begin{array}{l}\text { Calphostin C, before and after } \\
\text { CP-stim }\end{array}$ & ISL & Abolishes & {$[68]$} \\
\hline & \multirow[t]{5}{*}{ Rabbit } & $1 x(5 I+10 R)$ & $30 \mathrm{I}(180 \mathrm{R})$ & $\begin{array}{l}\text { Staurosporine, } 5 \text { min after } \\
\text { CP-stim }\end{array}$ & ISL & Abolishes & \multirow[t]{2}{*}{ [52] } \\
\hline & & $1 x(5 I+10 R)$ & $30 \mathrm{I}(180 \mathrm{R})$ & $\begin{array}{l}\text { Polymyxin B, } 5 \text { min after } \\
\text { CP-stim }\end{array}$ & ISL & Abolishes & \\
\hline & & $1 \times(5 I+10 R)$ & $30 \mathrm{I}(180 \mathrm{R})$ & $\begin{array}{l}\text { Chelerythrine, } 8 \mathrm{~min} \text { after } \\
\text { CP-stim }\end{array}$ & ISL & Abolishes & {$[67]$} \\
\hline & & $1 x(5 I+10 R)$ & $30 \mathrm{I}(180 \mathrm{R})$ & Staurosporine, before CP-stim & ISL & Attenuates & {$[63]$} \\
\hline & & $1 x(5 I+10 R)$ & $30 \mathrm{I}(180 \mathrm{R})$ & $\begin{array}{l}\text { Colchicine, } 30 \mathrm{~min} \text { before } \\
\text { before CP-stim }\end{array}$ & ISL & Abolishes & \\
\hline & \multirow[t]{7}{*}{ Dog } & $4 \times(5 I+10 R)$ & $60 \mathrm{I}(240 \mathrm{R})$ & $\begin{array}{l}\mathrm{H}-7 \text { (IV), before, during and } \\
\text { after CP-stim }\end{array}$ & ISL & $\begin{array}{l}\text { Failed to } \\
\text { abolish }\end{array}$ & \multirow[t]{3}{*}[64]{} \\
\hline & & $4 x(5 I+10 R)$ & $60 \mathrm{I}(240 \mathrm{R})$ & $\begin{array}{l}\text { H-7 (IC), before, during and } \\
\text { after CP-stim }\end{array}$ & ISL & $\begin{array}{r}\text { Failed to } \\
\text { abolish }\end{array}$ & \\
\hline & & $4 \times(5 I+10 R)$ & $60 \mathrm{I}(240 \mathrm{R})$ & $\begin{array}{l}\text { Polymyxin } \mathrm{B} \text {, before, during } \\
\text { and after CP-stim }\end{array}$ & ISL & $\begin{array}{l}\text { Failed to } \\
\text { abolish }\end{array}$ & \\
\hline & & $4 \times(5 I+5 R)$ & $90 \mathrm{I}(360 \mathrm{R})$ & $\begin{array}{l}\text { Polymyxin } \mathrm{B}, 5 \mathrm{~min} \text { before and } \\
\text { during } \mathrm{CP} \text {-stim }\end{array}$ & ISL & Abolishes & \multirow[t]{4}{*}[28]{} \\
\hline & & $4 x(5 I+5 R)$ & $90 \mathrm{I}(360 \mathrm{R})$ & $\begin{array}{l}\text { GF109203X, } 5 \mathrm{~min} \text { before and } \\
\text { during CP-stim }\end{array}$ & ISL & Abolishes & \\
\hline & & Methoxamine & $90 \mathrm{I}(360 \mathrm{R})$ & $\begin{array}{l}\text { Polymyxin } \mathrm{B}, 5 \mathrm{~min} \text { before and } \\
\text { during } \mathrm{CP} \text {-stim }\end{array}$ & ISL & Abolishes & \\
\hline & & Methoxamine & $90 \mathrm{I}(360 \mathrm{R})$ & $\begin{array}{l}\text { GF109203X, } 5 \mathrm{~min} \text { before and } \\
\text { during CP-stim }\end{array}$ & ISL & Abolishes & \\
\hline & \multirow[t]{2}{*}{ Pig } & $2 \times(10 I+30 R)$ & $60 \mathrm{I}(120 \mathrm{R})$ & Staurosporine & ISL & $\begin{array}{l}\text { Failed to } \\
\text { abolish }\end{array}$ & \multirow[t]{2}{*}{ [69] } \\
\hline & & BIS & $60 \mathrm{I}(120 \mathrm{R})$ & Bisindolylmaleimide & ISL & Mimics & \\
\hline
\end{tabular}

$\mathrm{I}=$ ischemia; $\mathrm{R}$ = reperfusion; $\mathrm{CP}=$ cardioprotective; $\mathrm{BIS}=$ bisindolylmaleimide; $\mathrm{H}-7$ = 1-(5-isoquinolinesulfonyl)-2-methylpiperazine; ISL $=$ infarct size limitation; $F R=$ functional recovery. 
Table 2. Protein kinase $C$ activators and myocardial infarct size.

\begin{tabular}{|c|c|c|c|c|c|c|}
\hline Model & Species & CP-Stimulus & $\begin{array}{l}\text { Prolonged- } \\
\text { Ischemia } \\
\mathrm{I}(\mathrm{R})(\mathrm{min})\end{array}$ & $\begin{array}{l}\text { Evaluation } \\
\text { (ISL/FR) }\end{array}$ & Result & Reference \\
\hline \multirow[t]{4}{*}{ Isolated heart } & Rat & $\mathrm{SAG}$ & $20 \mathrm{I}(40 \mathrm{R})$ & FR & Mimics & {$[48]$} \\
\hline & Rabbit & PMA & $30 \mathrm{I}(180 \mathrm{R})$ & ISL & Mimics & {$[52]$} \\
\hline & & $\mathrm{OAG}$ & $30 \mathrm{I}(180 \mathrm{R})$ & ISL & Mimics & \\
\hline & & PMA & $30 \mathrm{I}(120 \mathrm{R})$ & ISL & Mimics & {$[63]$} \\
\hline \multirow[t]{3}{*}{ In Vivo } & Rat & DOG & $45 \mathrm{I}(150 \mathrm{R})$ & ISL & Mimics & [53] \\
\hline & Rabbit & PMA & $30 \mathrm{I}(180 \mathrm{R})$ & ISL & Mimics & [63] \\
\hline & Pig & PMA & None & ISL & Failed to mimic & [69] \\
\hline
\end{tabular}

$\mathrm{I}=$ ischemia; $\mathrm{R}=$ reperfusion; $\mathrm{CP}=$ cardioprotective; $\mathrm{SAG}=1$-stearoyl-2-arachidonoyl glycerol; $\mathrm{PMA}=$ phorbol-12-myristate-13-acetate; $\mathrm{OAG}=$ oleyl acetyl-glycerol; DOG = 1,2-dioctanoyl sn-glycerol; ISL = infarct size limitation; FR = functional recovery.

Table 3. Protein kinase C translocation/activation and protection by ischemic preconditioning.

\begin{tabular}{|c|c|c|c|c|c|c|}
\hline Model & Species & $\begin{array}{l}\text { CP-Stimulus } \\
x(I+R)(\min )\end{array}$ & $\begin{array}{l}\text { Prolonged- } \\
\text { Ischemia } \\
\text { I(R) (min) }\end{array}$ & PKC assay & Result & Reference \\
\hline \multirow[t]{2}{*}{ Isolated heart } & \multirow[t]{2}{*}{ Rat } & $1 \times(2 I)$ & None & Immunohistofluorescence & $\begin{array}{l}\mathrm{PKC}-\delta \text { to sarcolemma, } \epsilon \text { to } \\
\text { nucleus, no } \zeta, \alpha, \beta_{1}\end{array}$ & {$[48]$} \\
\hline & & Phenylephrine & None & Immunohistofluorescence & $\begin{array}{c}\text { PKC- } \delta \text { to sarcolemma, } \zeta \text { to } \\
\text { nucleus, no } \epsilon, \alpha, \beta_{1}, \eta\end{array}$ & \\
\hline \multirow[t]{10}{*}{ In Vivo } & \multirow[t]{5}{*}{ Dog } & $4 \times(5 I+10 R)$ & None & $\begin{array}{l}\text { Fluorescent to binding by } \\
\text { confocal microscopy }\end{array}$ & No PKC translocation & \multirow[t]{5}{*}[64]{} \\
\hline & & $4 \times(5 I+10 R)$ & None & $\begin{array}{l}\text { Activity by protein } \\
\text { phosphorylation }\end{array}$ & No PKC activation & \\
\hline & & None & $10 \mathrm{I}$ & $\begin{array}{l}\text { Activity by protein } \\
\text { phosphorylation }\end{array}$ & $\mathrm{PKC}$ activation vs Con & \\
\hline & & $4 \times(5 I+10 R)$ & $10 \mathrm{I}$ & $\begin{array}{l}\text { Activity by protein } \\
\text { phosphorylation }\end{array}$ & PKC activation vs Con & \\
\hline & & PMA & None & $\begin{array}{l}\text { Activity by protein } \\
\text { phosphorylation }\end{array}$ & PKC activation & \\
\hline & $\operatorname{Dog}$ & $4 \times(5 I+5 R)$ & None & $\begin{array}{l}\text { Activity by protein } \\
\text { phosphorylation }\end{array}$ & PKC activation & {$[28]$} \\
\hline & \multirow[t]{2}{*}{ Pig } & $1 \times(10 I+7.5 R)$ & None & $\begin{array}{l}\text { Immunoreactivity on } \\
\text { Western blot }\end{array}$ & PKC $-\epsilon$ translocation & \multirow[t]{2}{*}[58]{} \\
\hline & & $1 \times(10 I+7.5 R)$ & None & $\begin{array}{l}\text { Activity by protein } \\
\text { phosphorylation }\end{array}$ & PKC $-\epsilon$ translocation & \\
\hline & \multirow[t]{2}{*}{ Pig } & $2 \times(10 I+30 R)$ & None & $\begin{array}{l}\text { Activity by protein } \\
\text { phosphorylation }\end{array}$ & PKC activation & \multirow[t]{2}{*}{ [69] } \\
\hline & & PMA & None & $\begin{array}{l}\text { Activity by protein } \\
\text { phosphorylation }\end{array}$ & PKC activation & \\
\hline
\end{tabular}

$\mathrm{I}=$ ischemia $; \mathrm{R}=$ reperfusion $\mathrm{CP}=$ cardioprotective $; \mathrm{PMA}=$ phorbol-12-myristate-13-acetate $\mathrm{PKC}=$ protein kinase $\mathrm{C}$

that in that study the low dose of PMA activated an isotype that is protective, while at the higher dose an isotype was activated that was damaging [78].

\section{Measurements of protein kinase \\ C-translocation (activation) (Table 3)}

Translocation of protein kinase $\mathrm{C}$ from the cytosol to the membrane has been investigated employing: (1) immunoblot analysis using protein kinase C isotype-specific antibodies of SDS-electrophoretically separated subcellular fractions isolated from myocardial homogenates $[44,51,69]$; (2) immunohistofluores- cence detection (with confocal microscopy) of protein kinase $\mathrm{C}$ isotypes in sections of myocardial tissue $[48,64]$; (3) assay of total protein kinase $\mathrm{C}$ activity in subcellular fractions isolated from myocardial homogenates by measurement of $\mathrm{Ca}^{2+}$ - and/or 1,2-DAGdependent ${ }^{32} \mathrm{P}$ incorporation from $\gamma_{-}{ }^{32} \mathrm{P}$-labelled ATP into histone III-S or a protein kinase $\mathrm{C}$ isoenzymespecific substrate protein such as peptide- $\epsilon$ $[51,54,64,79]$ or other peptides $[28,64]$. All three methods have their limitations. For instance, in protein phosphorylation or immunoreactivity assays, cardiac biopsies are usually rapidly frozen in liquid $\mathrm{N}_{2}$, 
followed by preparation of particulate fractions from the homogenates. It can not be excluded, however, that redistribution or (in) activation occurs during isolation of the subcellular fractions. In the subfractions both the basal rate and the maximum rate of histone III-S (or other substrate protein) phosphorylation are measured in the presence of $\mathrm{Ca}^{2+}$, PtdSer and 1,2DAG. The results of these measurements only reflect the total protein kinase $\mathrm{C}$ activities in the subcellular fractions. Moreover, histone III-S is a relatively poor substrate for some nPKC's $(\delta, \epsilon$ and $\eta)$ compared to the $\mathrm{cPKC}$ 's [41]. Therefore, measurements of the rate of ${ }^{32} \mathrm{P}$ incorporation into the synthetic protein kinase $\mathrm{C}-\epsilon$-specific substrate peptide- $\epsilon$ may provide the required information about the $\epsilon$ isotype [51]. It should also be noted that mixed micelles of $\mathrm{Ca}^{2+}-1,2-\mathrm{DAG}$ PtdSer embedded in Triton-X-100 micelles, used to activate protein kinase $\mathrm{C}$ in the ${ }^{32} \mathrm{P}$ incorporation assays, only mimic the cellular membrane environment of protein kinase $\mathrm{C}$ in the intact cell. It is unknown whether myocardium is preconditioned homogenously or heterogeneously. In the latter case, the sampling site of the biopsy may pose a restriction. Because protein kinase $\mathrm{C}$ assayed in subcellular fractions isolated from homogenates of whole myocardial tissue represents a mixture of activities of myocytes, fibroblasts, smooth muscle cells and endothelial cells, immunohistofluorescence measurements must therefore be performed to provide information on the cell type involved in protein kinase $\mathrm{C}$ translocation/activation. Measurements of protein kinase $\mathrm{C}$ isotype activity by immunohistofluorescence must, however, be interpreted with caution, because the specific antibodies are not always capable to distinguish active from inactive protein kinase $\mathrm{C}$ isotypes.

Weinbrenner et al, using Western blotting, showed in rats a rapid translocation of the $\mathrm{Ca}^{2+}$-dependent protein kinase $\mathrm{C}$ isotype $\alpha$ and the $\mathrm{Ca}^{2+}$-independent isotypes $(\delta, \epsilon$ and $\zeta)$ to the sarcolemma after brief ischemia and increased expression of the $\mathrm{Ca}^{2+}$. independent protein kinases C- $\delta$ and $\epsilon$ in the cytosol after prolonged ischemia [24]. Mitchell et al, using immunohistofluorescence, showed in rat hearts that protein kinase C- $\delta$ translocated from the cytosol to the sarcolemma after both brief ischemia and $\alpha_{1}$ adrenergic stimulation [48]. Brief ischemia also caused translocation of protein kinase $\mathrm{C}-\epsilon$ from the cytosol to the nuclear region. Measurements of other protein kinase C-isotypes $\left(\alpha, \beta_{1}, \zeta\right.$ and $\eta$ ) did not provide evidence for occurrence of translocation after brief ischemia or $\alpha_{1}$-adrenergic stimulation [48]. These results provide the first evidence that (at least in the rat) specific protein kinase $C$ isotypes are involved in ischemic preconditioning.

Przyklenk et al used a probe consisting of the protein kinase $\mathrm{C}$ inhibitor bisindolylmaleimide conjugated to fluorescein that selectively binds to active protein kinase $\mathrm{C}$ and observed no difference in the total amount and the cellular distribution of protein kinase
C fluorescence with preconditioning in dogs [64]. The advantage of this method over immunofluorescence is that it distinguishes between active and inactive protein kinase C. In their study Przyklenk et al also obtained quantitative information on the changes in the amount and subcellular distribution of protein kinase $\mathrm{C}$ by measuring the rate of ${ }^{32} \mathrm{P}$ incorporation into the threonine group of a protein kinase C-specific peptide, which was not further specified [64]. A small rise in protein kinase $\mathrm{C}$ activity was found in the membrane fraction isolated from biopsies obtained after $10 \mathrm{~min}$ of ischemia compared to those isolated after four sequences of 5 min occlusion-reperfusion or no intervention [64]. However, no difference in protein kinase $\mathrm{C}$ activity between matched groups of controls and 'ischemic preconditioned' dogs could be measured at time points comparable to the onset of the long occlusion or at $10 \mathrm{~min}$ into sustained ischemia [64]. Using the same protein kinase $\mathrm{C}$ analysis, Vogt et al found a modest (10 to $20 \%$ ) redistribution of protein kinase $\mathrm{C}$ from the cytosol to the membrane fraction in pig hearts subjected to $10 \mathrm{~min}$ of ischemia [69]. In contrast to the studies by Przyklenk et al [64], Kitakaze et al [28] observed in the same canine model a marked translocation of $\mathrm{Ca}^{2+}$ - and lipid-dependent protein kinase $\mathrm{C}$ activity in cytosol and membrane fractions isolated from preconditioned epi- as well as endomyocardium. These authors ascribed their positive findings to the time of measurements ( $5 \mathrm{~min}$ after the preconditioning stimulus against 10 min by Przyklenk et al [64]).

We studied translocation of protein kinase $\mathrm{C}$ enzyme activity by ${ }^{32} \mathrm{P}$ incorporation into histone III-S and $\epsilon$-peptide and immunoreactivity of a number of protein kinase $C$ isoforms ( $\alpha, \epsilon, \delta$ and $\zeta$ ) of cytosolic and membrane fractions isolated from biopsies of porcine myocardium preconditioned by a 10 -minute coronary artery occlusion and 7.5-minutes of reperfusion $[51,80] . \mathrm{Ca}^{2+}$ and 1,2-DAG-stimulated protein kinase $\mathrm{C}$ activity with histone III-S as substrate was higher in the cytosolic and particulate fractions isolated from the preconditioned myocardium than from the control region. Significant $\mathrm{Ca}^{2+}$-independent, 1,2-DAGstimulated phosphorylation of $\epsilon$-peptide was found in the cytosolic fractions, but not in the particulate fractions. However, no significant increase of 1,2-DAGstimulated phosphorylation of e-peptide in the cytosolic fraction from the preconditioned myocardium was observed. These were rather unexpected findings in view of our protein kinase $\mathrm{C}-\epsilon$ immunoreactivity measurements (see below). The cytosolic and particulate fractions were also examined by immunoblot analysis using rabbit polyclonal antibodies specific for protein kinase $\mathrm{C}-\alpha,-\delta,-\epsilon$ and $-\zeta$ isotypes [51]. This analysis revealed significant levels of expression of the $\mathrm{Ca}^{2+}$-independent isotype protein kinase $\mathrm{C}-\epsilon$, the abundant presence of protein kinase C- $\alpha$, while protein kinase $\mathrm{C}-\delta$ and $-\zeta$ were barely undetectable. The immunoreactivity data also indicate that neither the 
$\left(\mathrm{Ca}^{2+}\right.$ and 1,2-DAG)-stimulated histone III-S and peptide- $\epsilon$ kinase activities of the cytosolic nor those of the particulate fractions reflect the relative immunoreactivities in the corresponding fractions. In contrast to the ${ }^{32} \mathrm{P}$-incorporation data, the immunofluorescence data suggested that the total amount and subcellular distribution of protein kinase $\mathrm{C}-\alpha$ and $-\epsilon$ was not altered in the preconditioned region compared to the non-ischemic region of the left circumflex coronary artery. Therefore, by using immunofluorescence we were unable to detect the occurrence of ischemiainduced expression of protein kinase $\mathrm{C}$ or ischemiainduced translocation of protein kinase $\mathrm{C}$ from the cytosolic to the particulate fraction of the protein kinase $\mathrm{C}$ isotype $-\alpha,-\delta,-\epsilon$ or $\zeta$. On the other hand, binding proteins, such as myristoylated-alanine-rich-C-kinasesubstrate (MARCKS) and RACK may determine whether activated protein kinase $\mathrm{C}$ isotypes translocate and are providing another mechanism for functional specificity to specific intracellular locations. Thus, in the in vitro phosphorylation assays of the subcellular fractions, different amounts of MARCKSor RACK-bound protein kinase $\mathrm{C}$ isotypes can alter the protein kinase $\mathrm{C}$ activity measured [81]. This could cause the discrepancy between the activity assays and Western blotting. Nevertheless, our results on ${ }^{32} \mathrm{P}$ incorporation demonstrate an increase in cytosolic and membrane-bound protein kinase $\mathrm{C}$ activities due to brief ischemia and supports a role for protein kinase $\mathrm{C}$ in ischemic preconditioning in pigs [51].

\section{Concluding Remarks}

At present MARCKS is the only endogenous target protein for protein kinase $\mathrm{C}$, that has been shown to be phosphorylated in preconditioned rabbit myocardium. However, the former is believed to be an intracellular location site rather than a protein factor intimately involved in the protective response [82]. Irrespective of the target protein(s) we are dealing with, its (their) covalently bound phosphates must be relatively stable during the 2 to 3 hours in which the cardioprotection is present (CPP). Furthermore, the precise time point that protein kinase $\mathrm{C}$ is maximally translocated (activated) during ischemia or reperfusion (preconditioning stimulus) is unknown and consequently also the time point at which the enzyme reaches the target proteins for catalyzing their phosphorylation. It is quite feasible that protein kinase $\mathrm{C}$ is removed from its translocation site or proteolytically degraded after it has performed its action and thereafter it is no longer detectable by immunoreactivity or activity measurements. It is therefore mandatory to determine the time course of translocation/ activation and subsequent relocalization/inactivation or proteolytic degradation of the protein kinase $\mathrm{C}$ isotype and the time course(s) of phosphorylation and dephosphorylation or proteolytic degradation of the target protein(s). Because the time course of weaning of the protective effect of the CPP is roughly known, the time course of dephosphorylation/inactivation of the target protein could be correlated to the time course of weaning of protection. Candidate target proteins of protein kinase $\mathrm{C}$ involved in the CPP are e.g. the $\mathrm{K}_{\mathrm{ATP}}^{+}$channel $[13,14]$ and/or the ecto-5'nucleotidase [28], but experimental evidence for phosphate incorporation into these proteins or regulating proteins is lacking. If the $\mathrm{K}_{\mathrm{ATP}}^{+}$channel or the ecto-5'nucleotides are target proteins the most likely translocation site for the protein kinase $\mathrm{C}$ isotype(s) involved in the CPP is the sarcolemma.

Protein kinase $\mathrm{C}$ is involved in the agonist-receptor interaction induced changes in gene expression of many cells $[25,36,37,41,74,75,83]$. Taking into account the time required for inducing heat shock/stress proteins $[29,30]$ the former may only play a role in SWOP. Therefore, a transcription factor involved in the regulation of expression of heat shock/stress proteins could be another potential target protein of protein kinase $\mathrm{C}$. If true, the nucleus may be the translocation site for the protein kinase $\mathrm{C}$ isotype(s).

\section{Acknowledgment}

This study was supported by the Netherlands Heart Foundation (grant 95.103), the Netherlands Organization for Scientific Research (NWO) (grant nr 900-516-146) and the European Economic Community (grant nr CIPA-CT-4009).

\section{References}

1. Murry CE, Jennings RB, Reimer KA. Preconditioning with ischemia: a delay of lethal cell injury in ischemic myocardium. Circulation 1986;75:1124-1136.

2. Lawson CS, Downey JM. Preconditioning: state of the art myocardial protection. Cardiovasc Res 1993;27:542-550.

3. Zager RA, Baltes LA, Sharma HM, Jurkowitz MS. Responses of the ischemic acute renal failure kidney to additional ischemic events. Kidney Int 1984;26:689-700.

4. Lloris-Carsi JM, Cejalvo D, Toledo-Pereyra LH, Calvo MA, Suzuki S. Preconditioning: effect upon lesion modulation in warm liver ischemia. Transplant Proc 1993;25: 3303-3304.

5. Mounsey RA, Pang CY, Forrest C. Preconditioning: a new technique for improved muscle flap survival. Otolaryngology-Head and Neck Surg 1992;107:549-552.

6. Kitagawa $\mathrm{K}$, Matsumoto $\mathrm{M}$, Tagaya $\mathrm{M}$, Hata R, Ueda $\mathrm{H}$, Niinobe M, Handa N, Fukunaga R, Kimura K, Mikoshiba $\mathrm{K}$, Kamada $\mathrm{T}$. 'Ischemic tolerance' phenomenon found in the brain. Brain Res 1990;528:21-24.

7. Gho BC, Schoemaker RG, Van den Doel MA, Duncker DJ, Verdouw PD. Myocardial protection by brief ischemia in non-cardiac tissue. Circulation 1996;94:2193-2200.

8. Kuzuya T, Hoshida S, Yamashita N, Fuji H, Oe H, Hori M, Kamada T, Tada. Delayed effects of sublethal ischemia on the acquisition of tolerance to ischemia. Circ Res 1993; $72: 1293-1299$. 
9. Marber MS, Latchman DS, Walker M, Yellon DM. Cardiac stress protein elevation 24 hours after brief ischemia or heat stress is associated with resistance to myocardial infarction. Circulation 1993;88:1264-1272.

10. Baxter GF, Goma FM, Yellon DM. Duration of the "second window of protection" following ischaemic preconditioning in the rabbit. $J$ Mol Cell Cardiol 1995;27:A162 (Abstract).

11. Thornton J, Liu GS, Olsson RA, Downey JM. Intravenous pretreatment with A1-selective adenosine analogues protects the heart against infarction. Circulation 1992;85: 659-665.

12. Toombs CF, McGee DS, Johnston WE, Vinten-Johanson J. Myocardial protective effects of adenosine: infarct size reduction with pretreatment and continued receptor stimulation during ischemia. Circulation 1992;86:986-994.

13. Gross GJ, Auchampach JA. Blockade of ATP-sensitive potassium channels prevents myocardial preconditioning in dogs. Circ Res 1992;70:223-233.

14. Rohmann S, Weygandt $H$, Schelling $P$, Soei LK, Verdouw $\mathrm{PD}$, Lues I. Involvement of ATP-sensitive potassium channels in preconditioning protection. Basic Res Cardiol 1994; 89:563-576.

15. Downey JM, Cohen MV, Ytrehus K, Liu Y. Cellular mechanisms in ischemic preconditioning: The role of adenosine and protein kinase C. Ann NY Acad Sci 1994;723:882-898.

16. Wall TM, Sheehy R, Hartman JC. Role of bradykinin in myocardial preconditioning. $J$ Pharmacol Exp Ther 1994; 270:681-689.

17. Goto M, Liu Y, Yang X-M, Ardell JL, Cohen MV, Downey $\mathrm{JM}$. Role of bradykinin in protection of ischemic preconditioning in rabbit heart. Circ Res 1995;77:611-621.

18. Hu K, Nattel S. Mechanisms of ischemic preconditioning in rat hearts. Involvement of alpha $1 \mathrm{~B}$-adrenoceptors, pertussis toxin-sensitive G proteins, and protein kinase C. Circulation 1995;92(8):2259-2265.

19. Strasser RH, Marquetant R. Sensitization of the betaadrenergic system in acute myocardial ischaemia by a protein kinase C-dependent mechanism. Eur Heart $J$ 1991;12 Suppl F:48-53.

20. Yao Z, Gross GJ. Acetylcholine mimics ischemic preconditioning via a glibenclamide-sensitive mechanism in dogs. Am J Physiol. 264 (Heart Circ Physiol 33) 1993;H2221H2225.

21. Yao Z, Gross GJ. Role of nitric oxide, muscarinic receptors, and the ATP-sensitive $\mathrm{K}^{+}$channel in mediating the effects of acetylcholine to mimic preconditioning in dogs. Circ Res 1993;73:1193-1201.

22. Wang P, Gallagher KP, Downey JP, Cohen MV. Pretreatment with endothelin-1 mimics ischemic preconditioning against infarction in isolated rabbit heart. $J \mathrm{Mol}$ Cell Cardiol 1996;28:579-588.

23. Schultz JEJ, Hsu A, Gross GJ. Morphine-induced cardioprotection is mediated via the ATP-sensitive potassium channel in the rat heart (Abstract). FASEB J 1996;10:A12, 68.

24. Sugden PH, Bogoyevitch MA. Intracellular signalling through protein kinases in the heart. Cardiovasc Res 1995; $30: 478-492$.

25. De Jonge HW, Van Heugten HAA, Lamers JMJ. Signal transduction by the phosphatidylinositol cycle in myocardium. J Mol Cell Cardiol 1995;27:93-106.

26. Cohen MV, Downey JM. Preconditioning during ischemia: basic mechanism and potential clinical applications. Cardiol Rev 1995;3:137-149.

27. Hu K, Duan D, Nattel S. Protein kinase C-mediated activa- tion of ATP-sensitive potassium current-The missing link in ischemic preconditioning. Circulation 1995;92:22592265.

28. Kitakaze M, Node K, Minamino T, Komamura K, Funaya H, Shinozaki Y, Chujo M, Mori H, Inoue M, Hori M, Kamada $T$. Role of activation of protein kinase $C$ in the infarct size-limiting effect of ischemic preconditioning through activation of ecto-5'-nucleotidase. Circulation 1996;93:781791.

29. Donnely TJ, Sievers RE, Visseren FLJ, Welch WJ, Wolfe CL. Heat shock protein induction in rats. A role for improved myocardial salvage after ischemia reperfusion. Circulation 1992;85:769-778.

30. Yellon DM, Pasini E, Cargnoni A, Marber MS, Latchman $\mathrm{DS}$, Ferrari R. The protective role of heat stress in the ischaemic and reperfused rabbit myocardium. $J \mathrm{Mol}$ Cell Cardiol 1992;24:895-907.

31. Sleph P, D'Alonzo A, Dzwonczyk S, Parham C, Darbenzio $\mathrm{R}$, Grover GJ. Preconditioning is not abolished by the delayed rectifier $\mathrm{K}^{+}(\mathrm{IKR})$ blocker dofetilide. FASE $B J 1996$; 10:A319-1841.

32. Yao Z, Gross GJ. Activation of ATP-sensitive potassium channels lowers threshold for ischemic preconditioning in dogs. Am J Physiol 1994;267:H1888-H1894.

33. Kemp BE, Parker MW, Hu S, Tiganis T, House C. Substrate and pseudosubstrate interactions with protein kinases: determinants of specificity. Trends Biochem Sci 1994;19:440-444.

34. Zeisel SH. Choline phospholipids: signal transduction and carcinogenesis. FASEB $J$ 1993;7:551-557.

35. Rozengurt E, Sinnet-Smith J, Van Sint J, Valverde AM. Protein kinase D (PKD): A novel target for diacylglycerol and phorbol esters. Mutation Res 1995;333:153-160.

36. Nishizuka Y. Intracellular signalling by hydrolysis of phospholipids and activation of protein kinase. C. Science 1992; 258:607-614

37. Pucéat M, Brown JH. Protein kinase $\mathrm{C}$ in the heart. In: Ed. Protein kinase C, Kuo JF. London: Oxford University Press 1994;249-268.

38. Mochly-Rosen D, Khaner H, Lopez J. Identification of intracellular receptor proteins for activated protein kinase $\mathrm{C}$. Proc Natl Acad Sci 1991;88:3997-4000.

39. Ron D, Mochly-Rosen D. An autoregulatory region in protein kinase C: the pseudoanchoring site. Proc Natl Acad Sci 1995;92:492-496.

40. Pears C, Stabel S, Cauzabon S, Parker P. Studies on the phosphorylation of protein kinase C- $\alpha$. Biochem $J$ 1992;283: 515-518.

41. Hug H, Sarre TF. Protein kinase C isozymes: divergence in signal transduction. Biochem $J$ 1993;291:329-343.

42. Kikkawa U, Go M, Koumoto J, Nishizuka Y. Rapid purification of protein kinase $\mathrm{C}$ by high performance liquid chromatography. Biochem Biophys Res Commun 1986;135: 636-643.

43. Ruzycky A. Protein kinase $\mathrm{C}$ and cardiovascular contractility. In: Eds. Gwathmey JK, Briggs GM, Allan PD, Heart failure, basic science and clinical aspects. New York: Marcel Dekker, Inc. 1993;285-305.

44. Weinbrenner CE, Simonis G, Marquetant R, Strasser RH. Selective regulation of calcium-dependent and calciumindependent subtypes of protein kinase $\mathrm{C}$ in acute and prolonged myocardial ischemia (Abstract). Circulation 1993; 88(Suppl 1):I-101.

45. Lamers JMJ, Eskildsen-Helmond YEG, Resink AM, De Jonge HW, Bezstarosti K, Sharma HS, Van Heugten HAA. 
Endothelin-1-induced phospholipase C- $\beta$ and D and protein kinase $\mathrm{C}$ isoenzyme signalling leading to hypertrophy in rat cardiomyocytes. J Cardiovasc Pharmacol 1995;26(suppl. 3): S100-S103.

46. Bogoyevitch MA, Parker PJ, Sugden PH. Characterization of protein kinase $\mathrm{C}$ isotype expression in adult rat heart. Circ Res 1993;72:757-767.

47. Rybin VO, Steinberg SF. Protein kinase C isoform expression and regulation in the developing heart. Circ Res 1994; 74:299-309.

48. Mitchell MB, Meng X, Ao L, Brown JM, Harken AH, Banerjee A. Preconditioning of isolated rat heart is mediated by protein kinase C. Circ Res 1995;76:73-81.

49. Taguchi K, Erdbrügger W, Phillip T, Michel CM. Identification of protein kinase $\mathrm{C}$ (PKC) isoforms in the rat cardiovascular tissues (Abstract). FASEB $J$ 1996;10:A683.

50. Gerardo JA, Lust RM. Expression of PKC isoforms in adult canine cardiac myocytes (Abstract). FASEB J 1996;10: A314.

51. Eskildsen-Helmond YEG, Gho BCG, Bezstarosti K, Dekkers DHW, Soei LK, Van Heugten HAA, Verdouw PD, Lamers JMJ. Exploration of the possible roles of phospholipase $\mathrm{D}$ and protein kinase $\mathrm{C}$ in the mechanism of preconditioning in the myocardium. Ann N Y Acad Sci, 1996;793: 210-225.

52. Ytrehus K, Liu Y, Downey JM. Preconditioning protect the ischemic rabbit heart by protein kinase $\mathrm{C}$ activation. $\mathrm{Am} \mathrm{J}$ Physiol 1994;266:H1145-H1152.

53. Speechly-Dick ME, Mocanu MM, Yellon DM. Protein kinase $\mathrm{C}$. Its role in ischemic preconditioning in the rat. Circ Res 1994;75:586-590.

54. Kloner RA, Przyklenk K, Whittaker P, Hale S. Preconditioning stimuli and inadvertent preconditioning. J Mol Cell Cardiol 1995;27:743-747.

55. Tsuchida A, Liu Y, Liu GS, Cohen MV, Downey JM. $\alpha_{1}-$ Adrenergic agonists precondition rabbit ischemic myocardium independent of adenosine by direct activation of protein kinase C. Circ Res 1994;75:576-585.

56. Liu Y, Tsuchida A, Cohen MV, Downey JM. Pretreatment with angiotensin II activates protein kinase $\mathrm{C}$ and limits myocardial infarction in isolated rabbit hearts. $J$ Mol Cell Cardiol 1995;27:883-892.

57. Guillemain I, Rossignol B. Protein kinase C and phospholipase D activation in rat parotid glands. FEBS Letters 1995; 363:13-16.

58. Eskildsen-Helmond YEG, Van Heugten HAA, Lamers JMJ. Regulation and functional significance of phospholipase D in myocardium. Mol Cell Biochem 1996;157: $39-48$.

59. Exton JH. Phosphatidylcholine breakdown and signal transduction. Biochem Biophys Acta 1994;1212:26-42.

60. Nakamura S, Nishizuka Y. Lipid mediators and PKC activation for the intracellular signalling network. $J$ Biochem 1994;115:1029-1034.

61. Johnson JA, Adak S, Mochly-Rosen D. Prolonged phorbol ester treatment down-regulates protein kinase $C$ isozymes and increases contraction rate in neonatal cardiac myocytes. Life Sciences 1995;57:1027-1038.

62. Cohen MV, Yang XM, Downey JM. Conscious rabbits become tolerant to multiple episodes of ischemic preconditioning. Circ Res 1994;74:998-1004.

63. Liu Y, Ytrehus K, Downey LM. Evidence that translocation of protein kinase $\mathrm{C}$ is a key event during ischemic preconditioning of rabbit myocardium. J Mol Cell Cardiol 1994; 26:661-668.
64. Przyklenk K, Sussman MA, Simkhovich BZ, Kloner RA. Does ischemic preconditioning trigger translocation of protein kinase $C$ in the canine model. Circulation 1995;92: 1546-1557.

65. Speechly-Dick ME, Grover GJ, Yellon DM. Does ischemic preconditioning in the human involve protein kinase $\mathrm{C}$ and the ATP-dependent $\mathrm{K}^{+}$channel. Studies of the contractile function after simulated ischemia in an atrial in vitro model. Circ Res 1995;77:1030-1035.

66. Bugge $\mathrm{E}$, Ytrehus $\mathrm{K}$. Ischemic preconditioning is protein kinase $\mathrm{C}$ dependent but not through stimulation of $\alpha$ adrenergic or adenosine receptors in the isolated rat heart. Cardiovasc Res 1995;29:401-406.

67. Liu Y, Cohen MV, Downey JM. Chelerythrine, a highly selective protein kinase $\mathrm{C}$ inhibitor, blocks the anti-infarct effect of ischemic preconditioning in rabbit hearts. Cardiovasc Drugs Ther 1994;8:881-882.

68. Li Y, Kloner RA. Does protein kinase C play a role in ischemic preconditioning in rat hearts? Am J Physiol 1995; 268:H426-H431.

69. Vogt A, Barancik M, Weihrauch D, Arras M, Podzuweit T, Schaper W. Protein kinase $C$ inhibitors reduce infarct size in pig hearts in vivo (Abstract). Circulation 1994;90(suppl. I): $\mathrm{I}-647$.

70. Tamaoki $T$. Use and the specificity of staurosporine, $\mathrm{UCN}-01$, and calphostin $\mathrm{C}$ as protein kinase inhibitors. Methods Enzymol 1991;201:340-347.

71. Kobayashi E, Nakano H, Morimoto M, Tamaoki T. Calphostin C (UCN-1028C), a novel microbial compound, is a highly potent and specific inhibitor of protein kinase C. Biochem Biophys Res Commun 1989;159:548-553.

72. Harding AE, Jaggar JH, Squires PE, Dunne MJ. Protein kinase $\mathrm{C}$ and the modulation of ATP-sensitive potassium channels in insulin-secreting cells. Biochem Soc Trans 1993; $21: 388 \mathrm{~S}$.

73. Harding EA, Jaggar JH, Squires PE, Dunne MJ. Polymyxin $B$ has multiple blocking actions on the ATP-sensitive potassium channel in insulin-secreting cells. Pfügers Arch (Eur J Phys) 1994;426:31-39.

74. Steinberg SF, Goldberg M, Rybin VO. Protein kinase C isoform diversity in the heart. $J$ Mol Cell Cardiol 1995;27: 141-153.

75. Harrington EO, Ware JA. Diversity of the protein kinase C gene family. Implications for cardiovascular disease. Trends Cadiovasc Med 1995;5:198-198.

76. Hug H, Sarre TF. Protein kinase C isoenzymes: divergence in signal transduction? Biochem $J$ 1990;291:329-343.

77. Mochly-Rosen D, Heinrich CJ, Cheever L, Khaner H, Simpson PC. A protein kinase C isoenzyme is translocated to cytoskeletal elements on activation. Cell Regul 1990;1: 693-706.

78. Cohen MV, Liu Y, Downey JM. Activation of protein kinase $\mathrm{C}$ is critical to the protection of preconditioning. In: Eds. Wainwright CL and Parrat JR. Myocardial preconditioning. New York: Chapman \& Hall; Texas (USA): R.G. Landes Company. 1996:185-206.

79. Schaap D, Parker PJ. Expression, purification, and charac-

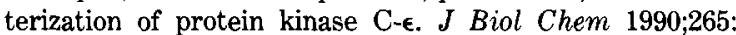
7301-7307.

80. Koning MMG, Simonis LAJ, De Zeeuw S, Nieukoop S, Pots $\mathrm{S}$, Verdouw PD. Ischaemic preconditioning by partial occlusion without intermittent reperfusion. Cardiovasc Res 1994; 28:1146-1151.

81. Mochly-Rosen D, Khaner H, Lopez J, Smith BL. Intracellular receptors for activated protein kinase $\mathrm{C}$, identification 
of a binding site for the enzyme. $J$ Biol Chem 1991;266: $14866-14868$.

82. Brooks G, Walsh R, Downey J. Phosphorylation of $80 \mathrm{~K} /$ MARCKS, a specific substrate of protein kinase $\mathrm{C}$ occurs after $5^{\prime}$ ischemia but only in preconditioned hearts (Abstract). Circulation 1993;88(SupplI):101.

83. Dekker LV, Parker PJ. Protein kinase C-a question of specificity. Trends Biochem Sci 1994;19:73-77. 